\title{
Author Correction: Human FCHO1 deficiency reveals role for clathrin-mediated endocytosis in development and function of $\mathrm{T}$ cells
}

\author{
Marcin Łyszkiewicz, Natalia Ziętara, Laura Frey, Ulrich Pannicke, Marcel Stern (1D, Yanshan Liu (1), Yanxin Fan, \\ Jacek Puchałka, Sebastian Hollizeck (1), Ido Somekh, Meino Rohlfs, Tuğba Yilmaz, Ekrem Ünal (1), \\ Musa Karakukcu (D, Türkan Patiroğlu (1), Christina Kellerer, Ebru Karasu, Karl-Walter Sykora, Atar Lev, \\ Amos Simon, Raz Somech, Joachim Roesler, Manfred Hoenig, Oliver T. Keppler, Klaus Schwarz \&
} Christoph Klein (D)

Correction to: Nature Communications https://doi.org/10.1038/s41467-020-14809-9, published online 25 February 2020.

In the original version of this Article, previous work by Calzoni et al. ${ }^{51}$ was inadvertently misrepresented in the penultimate paragraph of the Discussion. It incorrectly read 'Very recently, Calzoni et al. published a short letter and reported biallelic mutations in FCHO1 in four families. The phenotypes of these patients resembled the phenotype of our patients, but no functional experiments or proof-ofcausality was provided. Based on experiments in activated T-cell blasts, the authors concluded that in the absence of FCHO1, CME is globally affected. In contrast, our data support the concept that FCHO1 does not globally affect $\mathrm{CME}^{51}$.'

The correct version states 'While our study was under review, Calzoni et al. reported biallelic mutations in FCHO1 in four families ${ }^{51}$. The phenotypes of these patients resembled the phenotype of our patients. Based on experiments in activated T-cell blasts, the authors concluded that in the absence of FCHO1, CME of the transferrin receptor is affected ${ }^{51}$. In contrast, our data support the concept that FCHO1 does not control internalization of the transferrin receptor and mediates more subtle effects on CME.'

This has been corrected in both the PDF and HTML versions of the Article.

Published online: 20 April 2020

\footnotetext{
(c) (i) Open Access This article is licensed under a Creative Commons Attribution 4.0 International License, which permits use, sharing, adaptation, distribution and reproduction in any medium or format, as long as you give appropriate credit to the original author(s) and the source, provide a link to the Creative Commons license, and indicate if changes were made. The images or other third party material in this article are included in the article's Creative Commons license, unless indicated otherwise in a credit line to the material. If material is not included in the article's Creative Commons license and your intended use is not permitted by statutory regulation or exceeds the permitted use, you will need to obtain permission directly from the copyright holder. To view a copy of this license, visit http://creativecommons.org/licenses/by/4.0/.
}

(c) The Author(s) 2020 